\title{
Effects of Different Casing Inoculum Spawm on Yield and Quality of White Buttom Mushroom
}

\author{
Golgen Bahar Oztekin (Corresponding author) \\ Ege University, Faculty of Agriculture, Department of Horticulture \\ 35100 Bornova-Izmir, Turkey \\ E-mail: golgen.oztekin@ege.edu.tr \\ Haluk Sayin \\ Ege University, Faculty of Agriculture, Department of Horticulture \\ 35100 Bornova-Izmir, Turkey \\ E-mail: haluksayin@outlook.com
}

\begin{abstract}
This study was conducted to determine the effects of different casing inuculum (CI) sources on yield, quality and morphological developmant of white buttom mushroom (Agaricus bisporus) in 2016 autumnwinter period in the Ege University Faculty of Agriculture, Department of Horticulture. Two different CI spawms [A15 and $\mathrm{F} 1 \mathrm{Cl}]\left(100 \mathrm{~g} \mathrm{~m}^{-2}\right)$ was used. Commercial mushroom bags received from private company and spawms were applied on 16.11.2016 to casing layer. Experiment was finished after $3^{\text {rd }}$ flash on 04.01.2017. The total yield, fruit number, average fruit weight, quality values (the hat's diameter, height, stalk length, thichness and weight, carpophore weight, biomass, firmness, color, and vitamin C) and nutrient content was determined. The results obtained from experiment showd that CI was increased carpophore weight and fruit number. In addition, CI appication gave the positive effects on yield and quality of white buttom mushroom. Among the used CI, A15 had the better performance. It was concluted that studies should be continued with different sourge of CI and doses.
\end{abstract}

Keywords: Agaricus bisporus, A15, F1C1, casing layer, spawm.

DOI: $10.7176 /$ JSTR/6-08-01

\section{Farklı Toprak Miseli Uygulamasının Beyaz Şapkalı Mantar Yetiştiriciliğinde Verim ve Kaliteye Etkileri}

\begin{abstract}
Özet
Kullanılan farklı kaynaklı toprak misellerinin beyaz şapkalı kültür mantarı (Agaricus bisporus) yetiştiriciliğinde morfolojik gelişim, verim ve kalite üzerine etkisini belirlemek amacıyla, 2016 yılı sonbahar-kış döneminde mantar üretim odalarında yürütülen bu çalışmada iki farklı toprak miseli [A15 ve $\mathrm{F} 1 \mathrm{Cl}]\left(100 \mathrm{~g} / \mathrm{m}^{2}\right)$ kullanılmıştır. Ticari mantar işletmesinden alınan misel ekili kompostlu PE torbalarda yapılan mantar yetiştiriciliğinde, toprak miselleri 16.11.2016 tarihinde örtü toprağına uygulanmıştır. Deneme 3 flaş sonrası 04.01.2017 tarihinde sonlandırılmıştır. Araştırmada toplam verim, meyve sayısı, ortalama meyve ağırlığı, kalite değerleri (şapka çapı ve yüksekliği, sap uzunluğu ve kalınlığı, şapka ağırlığ 1 , karpofor ağırlığ1, biyokütle, sertlik, renk ve vitamin C) ve besin maddesi içerikleri belirlenmiştir. Elde edilen sonuçlar toprak miseli takviyesinin karpofor ağırlığı ve meyve sayısını arttırdığını; beyaz şapkalı kültür mantarı yetiştiriciliğinde toprak miseli kullanımının verim ve kalite açısından olumlu etkiler yaptığını; kullanılan toprak miselleri içerisinde A15'in daha iyi performansa sahip olduğunu göstermiştir. Ancak mantarda farklı toprak miselleri ve uygulama dozu ile ilgili çalışmalara devam edilmesi gerektiği önerilmiştir.
\end{abstract}

Anahtar Kelimeler: Agaricus bisporus, A15, F1Cl, örtü toprăğ, tohumluk misel. 


\section{Giriş}

Dünyada 68 ülkede üretimi yapılan yenilebilir mantarların (beyaz şapkalı, kestane, kayın, şitaki, kuzu göbeği, trüf, dede sakalı, saman, reishi, enoki, maitake mantarı vs) 2018 yılında üretim miktarı 15668543 ton olarak belirlenmiştir. Türkiye mantar üretimi 46144 ton olup, dünya sıralamasında \%0.29'uk bir payla 16. sirada yer almaktadır (FAOSTAT, 2020).

Dünyada ve ülkemizde en fazla yetiştirilen mantar türü beyaz şapkalı (Agaricus bisporus) mantarlardır. Bu türün dünya mantar üretiminin yıllara göre \%30-50'sini oluşturduğu bilinmektedir. Türkiye'de ticari olarak üretimi yapılan mantarın tamamına yakınının da $A$. bisporus türü olduğu, gün geçtikçe protein içerikleri zengin, verimli ve kültür işlemleri kolay yapılabilen Pleurotus türlerinin yetiştiriciliğine de ilginin arttığ görülmektedir (Aksu, 2006; Şen ve Yalçın, 2010).

Doğadan toplamaların ekolojik şartlara bağlı olması, yıl içerisinde sürekliliğinin olmaması, verimliliğinin düşük olması ve zehirleme riskleri mantarın kültüre alma çalışmalarını gündeme getirmiştir. İlk defa 16 yy.'da Fransa'da yapılan kültüre alma çalışmaları, günümüze kadar ulaşmıştır. Özellikle ölümlere bile neden olabilen zehirlenme sorunu sonucu olumsuz etkilenen mantar tüketiminde, kültüre alma çalışmaları ile birlikte artışlar olmuştur. Kültür mantarının kişi başına yıllık tüketim miktarı ülkeler arasında değişiklik göstermekle beraber AB ülkelerinde bu oran ortalama $2.64 \mathrm{~kg}$ iken, ülkemizde bu oranın oldukça düşük olduğu $(0.5 \mathrm{~kg}$ civarında) belirtilmiştir (Basım, 2019). Ülkemizdeki mantar üretimi son 20 yıl içerisinde (1998-2018) 15.4 kat artmıştır (FAOSTAT, 2020). Yıllar içerisinde ülkemizde mantar üretimi artış göstermesine rağmen, dünya sıralamasında üretim miktarımızın hala düşük olduğu, üretim ve tüketimimizin paralellik gösterdiği görülmektedir.

Ülkemiz mantarcılığında verimliliği arttırmaya yönelik çalışmalar yıllar içerisinde yer bulmuş ve devam etmektedir. Misellerden karpofor (şakpa+sap) oluşumu üzerine kullanılan kompsot reçetesi, örtü toprağı, pastörizasyon, kuluçka ve üretim odası ile kompost ekolojik koşulları, pH, kullanılan misel miktarı ve kalitesi, ilave misel aşılaması gibi faktörlerin etki yaptığı bilinmektedir (Aksu, 2006; Munshi et al., 2010). Bunlar içerisinde ilave misel aşılaması üzerinde çalışmaların yeni olduğu, ancak mantar verimini etkileyen önemli kriterler arasında yer aldığı ve ticari işletmelerde verim artışı sağlamak için kullanıldığ görülmektedir. Misel aşılaması değişik şekillerde uygulanabilmektedir. Bunlardan "toprak miseli uygulaması" örtü toprağına (casing) ilave misel uygulaması (inoculum) anlamına gelmekte İngilizce "Casing Inoculum" kelimesinin anlamını taşıyan "CI" ismi ile de anılmaktadır. Toprak miseli uygulaması, örtü toprağı materyallerine sardırılmış miselin örtü toprağına ilave edilerek karıştırılması şeklinde ilk kez 1960'lı yıllarda İrlanda'da geliştirilmiş ve 1972 yılında yazılı literatürde yerini almıştır (MacCanna and Flanagan; 1972; Royse and Beelman, 2016). Ancak son zamanlarda ticari mantar işletmelerinde örtü toprağına doğrudan ilave misellerin uygulandığı görülmektedir. Bu tür miseller tohumluk misel satan işletmeler tarafından "CI misel” adı altında toprak miseli olarak satışa sunulmaktadir (Anon., 2020).

Toprak miseli kullanımı örtü toprağı içerisinde daha hızlı ve homojen bir misel gelişimi sağlamak, pin oluşumunu desteklemek, misellerin buket şeklinde kümeleşme riskini azaltarak misellerin yayılmasını sağlamak, çıkışlardaki düzen nedeni ile ürün kalitesini artırmak ve hasadı kolaylaştırmak, flaş dönemine girişlerde denge sağlamak, örtü toprağı tırmıklama işlemini ortadan kaldırarak tırmıklamada kullanılacak işçilik maliyeti gidermek, daha kuvvetli bir misel gelişimi sağlayarak oluşabilecek hastalık riskini azaltmak, verimi arttırmak ve üretim süresinde 4-6 gün erkencilik sağlamak gibi faydalar sağlamaktadır (Vedder, 1989; Samp, 1993; Royse and Beelman, 2016; E. Eren, 2017 sözlü görüşme)

Yürütülen bu çalışmada piyasada bulunabilen ve ticari olarak kullanılan iki farklı toprak miseli (A15 ve F1C1) uygulamasının beyaz şapkalı mantar (Agaricus bisporus) yetiştiriciliğinde örtü toprağına doğrudan uygulanmasının mantar gelişimi, verim ve kalitesi üzerine etkisini belirlemek amaçlanmıştır.

\section{Materyal ve Yöntem}

Araştırma, 2016 yılı sonbahar-kış döneminde Ege Üniversitesi Ziraat Fakültesi Bahçe Bitkileri Bölümü'ne ait mantar üretim odalarında gerçekleştirilmiştir. Ürün materyali olarak beyaz şapkalı kültür mantarı (Agaricus bisporus), ilave toprak miseli olarak da orta boy beyaz şapkalı mantara ait A15 (Sylvan Spawn/ Pensilvanya, ABD) ve F1C1 (Spyra Spawn/Poland) miseli (100 g/m²) kullanılmıştır.

Ticari mantar işletmesinden (Pe-Ma Mantar, İzmir) temin edilen, misel ekilmiş ( $7 \mathrm{~kg}$ misel/ton kompost) 20 kg'luk, $45 \mathrm{~cm}$ çaplı kompost torbaları 26.10.2016 tarihinde hijyeni sağlanmış mantar üretim odasında raflara yerleştirilmiş ve komposta misel sarımı için hava sirkülasyonu olan $22-25^{\circ} \mathrm{C}$ sıcaklık ve \%90-95 nem koşulunda bekletilmiştir. Kuluçka aşaması sonlarına doğru, 09.11.2016 tarihinde misel sarımını arttırmak için tokmaklama işlemi yapılmış ve misellerin kompostu iyice sardığ1 11.11.2016 tarihinde örtü toprağı serimi yapılmıştır. Denemede kullanılan toprak miselleri tüm yetiştiricilik dönemi boyunca 1 defa olmak üzere deneme başladıktan 15 gün sonra örtü toprağı üzerinden uygulanmıştır. Firma beyanına göre $\left(100 \mathrm{~g} / \mathrm{m}^{2}\right)$ tartılan miseller örtü toprağına karıştırılmış ve örtü toprağ $5 \mathrm{~cm}$ kalınlıkta olacak şekilde

2 I P a g e www.iiste.org 
kompost üzerine serilmiştir. Torba yüzey alanı hesabına göre yapılan hesaplamada her torbaya $16 \mathrm{~g}$ toprak miseli uygulanmıştır.

Mantarların bakım işleri zamanı geldikçe Aksu (2006)'ya göre yapılmıştır. Tırmıklama işlemi yapılmamış, mantarların ihtiyacı olan su, gözlem esasına göre belirlenmiştir ve gerektikçe süzgeçli kova ile çeşme suyu verilmiştir. 20-23.11. 2016 tarihinde el pülverizatörü ile sinek ve nematoda karşı biyolojik ilaçlama (Cedrix ve Nimbedicine, Agrobest A.Ş/Kemalpaşa, İzmir) yapılmıştır. Oda içi nem ve sıcaklık değerleri dijital termometre ile (Medifine, İstanbul) anlık olarak ölçülmüştür. Ayrıca oda kontrol sistemi (Fancom 765, Hollanda) ile oda içi nem ve kompost sıcaklığı ölçülmüştür. Oda nemi ve sıcaklığı mantar gelişim dönemine göre manuel olarak ayarlanmıştır. Üretim dönemi boyunca oda içinde ölçülen sıcaklık değerleri misel ekim-örtü toprağı döneminde $20-26{ }^{\circ} \mathrm{C}$ arasında, hasat döneminde $16-18{ }^{\circ} \mathrm{C}$ arasında değişmiştir. Nem oranı tüm üretim dönemi boyunca \%80-90 olacak şekilde ayarlanmıştır

Hasatlar 04.12.2016 tarihinde başlamış ve üretim 04.01.2017 tarihinde üçüncü flaş bitiminde sonlandırılmıştır. Hasatta elde edilen mantarların ağırlıkları alınarak toplam adet, ağırlık, verim değerleri hesaplanmış, toplam verim değerlerinden zarar görmüş (hastalıklı, fizyolojik bozukluk gösteren mantarlar) çıkartılarak pazarlanabilir verim ve pazarlanamaz meyve oranı hesaplanmıştır. Hasatlardan elde edilen karpofor sayısı ve ağırlığı ortalama değer olarak verilmiştir.

04.12.2016 tarihinde yapılan birinci flaş ikinci hasadında her tekerrürden alınan 10 mantarda morfolojik gelişme (şapka çapı ve yüksekliği, sap uzunluğu ve kalınlığı, şapka açıklığı, şapka ağırlığı, karpofor ağırlığı) ve kalite değerleri (renk, sertlik, kuru madde ve vitamin C) belirlenmiştir. Kurutulan mantarlar öğütülerek elde edilen örneklerde $\mathrm{N}, \mathrm{P}, \mathrm{K}, \mathrm{Ca}, \mathrm{Mg}$, Fe içerikleri belirlenmiştir. Hasattan elde edilen şapkalar açıklıklarına göre oluşturulan skalada (0-4) değerlendirilmiştir. Buna göre; (0): kapalı şapka; (1): şapkanın \%25 açılmış hali, (2): şapkanın \%50 açılmış hali; (3): şapkanın \%75 açılmış hali, (4): tamamen açık (\%100) şapka olarak belirlenmiştir.

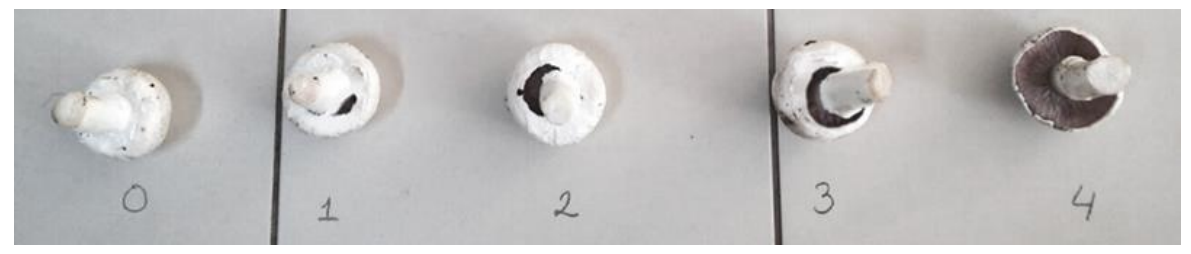

Şekil 1. Şapka açıklık skalası

Tesadüf parselleri deneme desenine göre tek faktör ile kurulan denemede her konu 3 tekrarlı olmuş, bir PE torba bir tekerrür olarak kabul edilmiştir. Araştırmadan elde edilen verilere, bilgisayarda JMP istatistik paket programı uygulanmış ortalamalar arasındaki fark TUKEY testine göre belirlenmiştir.

\section{Bulgular}

3.1. Verim değerleri

Hasatlar 1. flaşta 04.12.2016-13.12.2016, 2.flaşta 14.12.2016-26.12.2016, 3.flaşta 26.12.201604.01.2017 tarihleri arasında yapılmıştır. Toplam verim 20 kg'lık kompost torbalarında 4.64-5.29 $\mathrm{kg} /$ torba (23.20-26.45 kg/100 kg kompost) arasında değişmiştir. Uygulamaların 1. ve 2. flaş toplam verim değeri üzerine etkisi istatistiksel olarak önemli bulunurken, 3. flaş verimi uygulamalardan etkilenmemiştir (Şekil 2). En fazla verim 1. flaştan alınmıştır.

Toprak miseli uygulamasının pazarlanabilir verim üzerine etkisi sadece 1. flaşta istatistiksel olarak önemli bulunmuştur (Şekil 2). Toprak miseli uygulaması kültür mantarında pazarlanabilir verimini arttırmıştır. Kontrol uygulamasına göre F1C1 misel uygulaması 1. flaş verimini \%31.1 oranında, A15 misel uygulaması $\% 46.7$ oranında arttırmıştır.

1. Flaşta sadece F1C1 miseli uygulamasında \%0.26 oranında pazarlanamaz karpofor ağırlı̆̆ elde edilirken, 2. flaşta sadece kontrol uygulamasında \%20.5 oranında pazarlanamaz karpofor elde edilmiştir. En fazla pazarlanamaz karpofor oran1 3. flaşta görülmüş; kontrol, F1C1 ve A15 uygulamalarında bu oran sırası ile \%33.0, \%22.45 ve \%13.1 olmuştur. Flaş bazında uygulamalar arasında istatistiksel bir farklılık saptanmamış ancak toprak miseli uygulamasının pazarlanamaz karpofor yüzdesini düşürdüğü görülmüştür. A15 misel uygulaması bu konuda umutvar bulunmuş, toplam karpofor üretiminde pazarlanamaz ürün miktarını kontrole göre $\% 75.5$, F1C1 miseline göre $\% 42.3$ oranında azaltmıştır. 

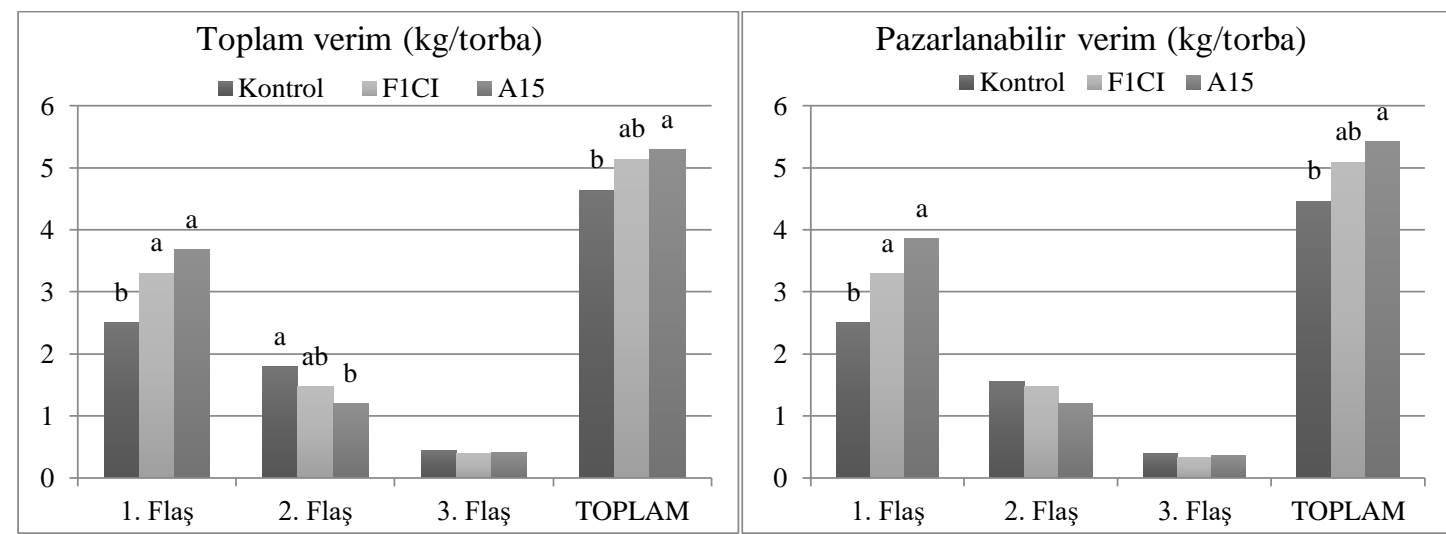

Şekil 2. Uygulamaların toplam ve pazarlanabilir verim üzerine etkileri (Her flaş verimi kendi içinde değerlendirilmiş, istatistiksel olarak harflendirilmiştir)

Karpofor sayısı ve ağırlı̆̆ı üzerine uygulamaların etkisi 3. flaş hariç önemli bulunmuştur (Şekil 3). A15 miseli uygulaması toplam karpofor sayısı ve ağırlığını arttırmıştır. İlave A15 misel uygulaması karpofor sayısını kontrole göre \%53.1, F1C1 misel uygulamasına göre \%17.9 oranında arttırmıştır. Karpofor ağırlığında ise söz konusu artış sırası ile $\% 27.5$ ve $\% 8.5$ olmuştur.
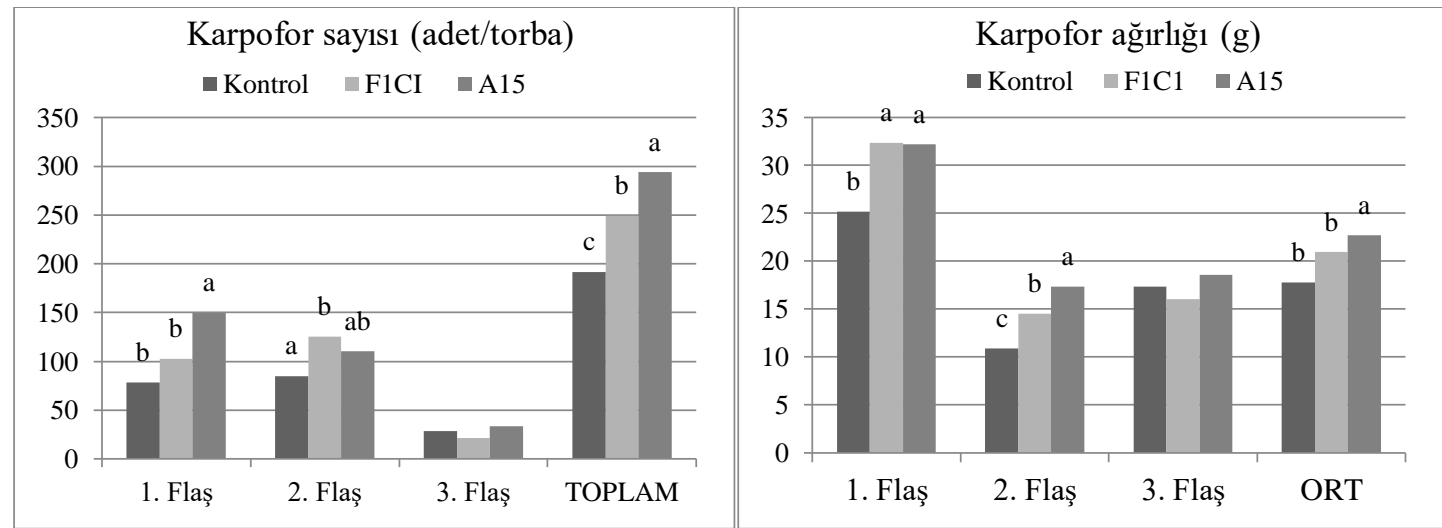

Şekil 3. Uygulamaların karpofor sayısı ve ortalama karpofor ağırlı̆̆ı üzerine etkileri (Her flaş verimi kendi içinde değerlendirilmiş, istatistiksel olarak harflendirilmiştir)

\subsection{Karpofor morfolojisi}

Uygulamaların sap kalınlığ1 ve uzunluğu ile sapka çapı ve yüksekliği üzerine etkisi istatistiksel olarak önemli bulunurken, analiz için seçilen pazarlanabilir örneklerde karpofor ve sapka ağırlığı üzerine etkisi önemsiz bulunmuştur (Şekil 4). Sap kalınlığı 14.8-21.77 mm arasında, sap uzunluğu 39.21-52.14 mm arasında, şapka çapı 42.2-42.9 mm arasında ve şapka yüksekliği 23.17-24.68 mm arasında değişmiştir. A15 misel uygulamasından alınan karpoforların sapları daha kalın ve uzun, sapka çapı daha geniş ve daha yüksek bulunmuştur. A15 misel uygulanmış torbalardan alınan mantarlarda karpofor ağırlığı ve sayısı yüksek olmuştur. En fazla pazarlanabilir korpofor ve şapka ağırlığı A15 uygulamasıyla elde edilmiştir (Şekil 4). 


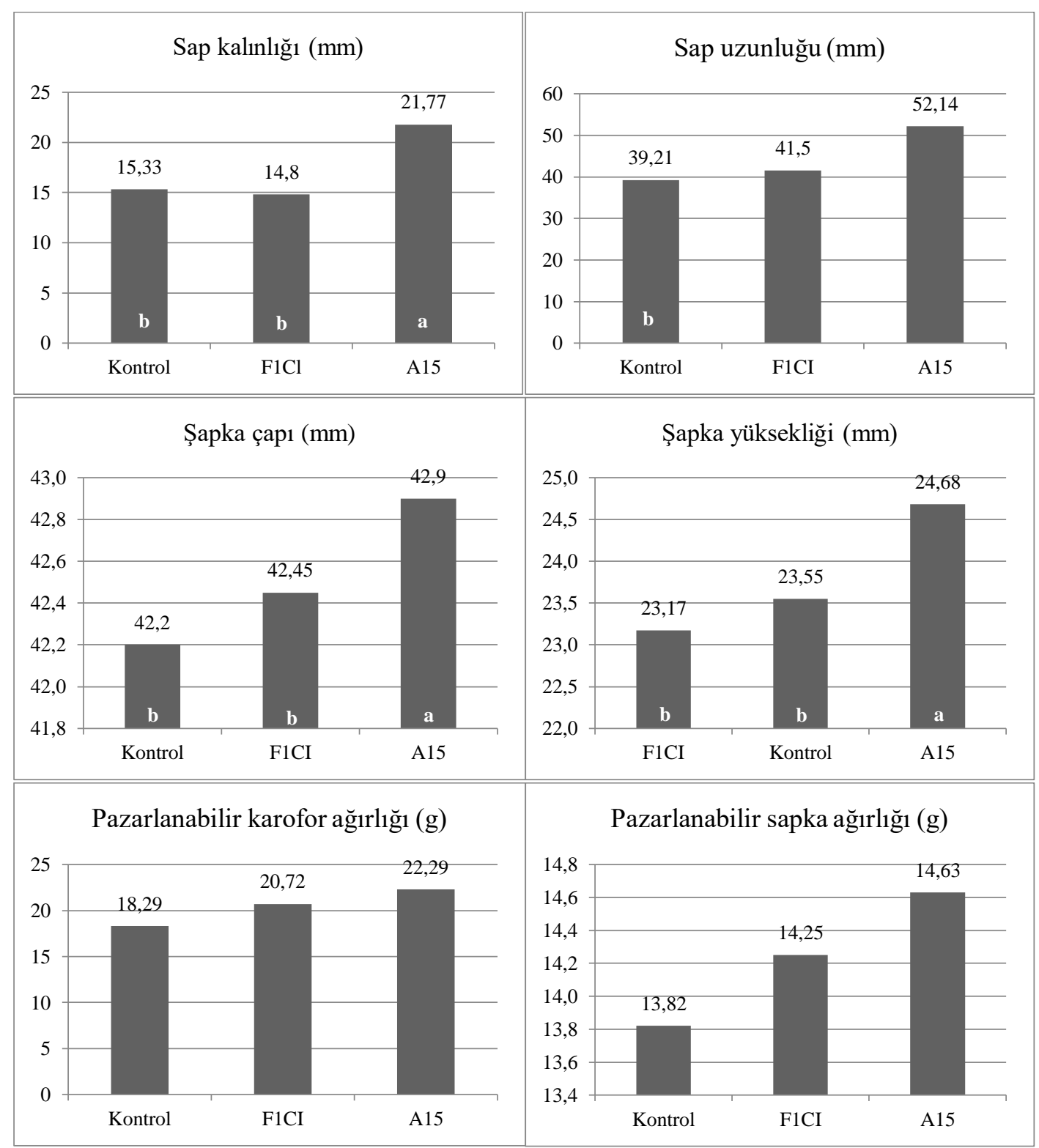

Şekil 4. Uygulamaların karpofor morfolojisine etkileri

Şapka açıklığı uygulamalardan etkilenmiş ve 0-4 skalasına göre yapılan değerlendirmede şapkaların açıklık oranının \%50'nin altında kaldığ1; kontrol uygulamasının açıklık oranının 0.60, A15 miseli uygulamasında şapkaların açıklık oranının 0.78 ve F1C1 miseli uygulamasında bu oranın 2.0 olduğu; kontrol ve A15 uygulamasının aynı istatistiksel grupta yer alırken F1C1 uygulamasının ayrı grupta yer aldığ1 görülmüştür. F1C1 uygulaması şapka açıklık oranını arttırmıştır. A15 toprak miseli uygulanmış ortamdan alınan mantarların açılma oranı F1C1 uygulamasına göre \%61 daha az, kontrole göre $\% 30$ fazla olmuştur.

\subsection{Kalite değgerleri}

Şapka rengi üzerine ilave misel uygulamasının etkisi $b^{*}$ ve Croma değeri hariç önemli bulunmuştur (Tablo 1). A15 misel uygulamasından elde edilen karpoforlar en parlak, beyaz rengi vermişlerdir. Toprak miseli uygulaması düşük $\mathrm{a} * / \mathrm{b}^{*}$ değeri ile daha beyaz renkli şapkalar oluşturmuştur.

Uygulamaların şapka sertliği ve kuru madde içeriği üzerine etkisi önemli bulunmuştur (Tablo 2). Toprak miseli uygulaması meyve sertliğini azaltmıștır. En sert şapkalar kontrol uygulamasından alınırken, A15 ve F1C1 toprak miseli uygulanmış mantar şapkaları aynı sertliği göstermiştir ve kontrole göre daha yumuşak olmuşlardır. Kuru ağırlık \%9.33 ile \%7.21 arasında değişmiş, toprak miseli uygulaması şapka kuru ağırlığını azaltmıştır. Uygulamaların vitamin C içeriği üzerine etkisi her ne kadar önemli bulunmamış olsa da A15 toprak miseli uygulaması ile vitamin C içeriği kısmen artış göstermiştir (Tablo 2). 
Tablo 1. Uygulamaların şapka renk değerleri üzerine etkisi

\begin{tabular}{|l|c|c|c|c|c|c|}
\hline Uygulamalar & $\mathrm{L}$ & $\mathrm{a}^{*}$ & $\mathrm{~b}$ & $\mathrm{a}^{*} / \mathrm{b}^{*}$ & Hue $^{\circ}$ & Croma $^{\circ}$ \\
\hline Kontrol & $87.89 \mathrm{~b}$ & $2.48 \mathrm{a}$ & 14.58 & $0.17 \mathrm{a}$ & $80.48 \mathrm{~b}$ & 14.80 \\
\hline $\mathrm{F} 1 \mathrm{Cl}$ & $89.98 \mathrm{a}$ & $0.91 \mathrm{~b}$ & 14.23 & $0.06 \mathrm{~b}$ & $86.35 \mathrm{a}$ & 14.26 \\
\hline $\mathrm{A} 15$ & $90.78 \mathrm{a}$ & $1.02 \mathrm{~b}$ & 14.27 & $0.07 \mathrm{~b}$ & $85.86 \mathrm{a}$ & 14.31 \\
\hline$P$ & $* *$ & $* *$ & öd & $* * *$ & $* * *$ & $\ddot{0} d$ \\
\hline
\end{tabular}

Tablo 2. Uygulamaların sertlik, kuru madde ve vitamin C içeriği üzerine etkileri

\begin{tabular}{|l|c|c|c|}
\hline Uygulamalar & $\begin{array}{c}\text { Sertlik } \\
(\mathrm{N})\end{array}$ & $\begin{array}{c}\text { Kuru madde } \\
(\%)\end{array}$ & $\begin{array}{c}\text { Vitamin C } \\
(\mathrm{mg} / 100 \mathrm{ml})\end{array}$ \\
\hline Kontrol & $7.37 \mathrm{a}$ & $9.33 \mathrm{a}$ & 5.35 \\
\hline $\mathrm{F} 1 \mathrm{Cl}$ & $6.86 \mathrm{~b}$ & $8.72 \mathrm{ab}$ & 5.34 \\
\hline $\mathrm{A} 15$ & $6.86 \mathrm{~b}$ & $7.21 \mathrm{~b}$ & 5.57 \\
\hline$P$ & $* * *$ & $*$ & öd \\
\hline
\end{tabular}

\subsection{Besin elementi içeriği}

Karpofor besin elementleri içeri üzerine uygulamaların etkisi sadece $\mathrm{N}$ içeriği üzerine önemli bulunmuştur. $\mathrm{P}, \mathrm{K}, \mathrm{Ca}, \mathrm{Mg}$ ve Fe içeriği ilave misel uygulamasından etkilenmemiştir. Toprak miseli uygulaması kültür mantarının $\mathrm{N}$ alınımını arttırmış, en yükssek $\mathrm{N}$ içeriği A15 miseli uygulamasından elde edilmiştir (Tablo 3).

Tablo 3. Uygulamaların karpofor besin elementi içeriği üzerine etkileri

\begin{tabular}{|l|c|c|c|c|c|c|}
\hline Uygulamalar & $\begin{array}{c}\mathrm{N} \\
(\%)\end{array}$ & $\begin{array}{c}\mathrm{P} \\
(\%)\end{array}$ & $\begin{array}{c}\mathrm{K} \\
(\%)\end{array}$ & $\begin{array}{c}\mathrm{Ca} \\
(\%)\end{array}$ & $\begin{array}{c}\mathrm{Mg} \\
(\%)\end{array}$ & $\begin{array}{c}\mathrm{Fe} \\
(\mathrm{ppm})\end{array}$ \\
\hline Kontrol & $3.87 \mathrm{~b}$ & 1.50 & 4.11 & 0.11 & 0.17 & 20.80 \\
\hline $\mathrm{F} 1 \mathrm{Cl}$ & $4.06 \mathrm{ab}$ & 1.42 & 4.11 & 0.10 & 0.17 & 19.03 \\
\hline $\mathrm{A} 15$ & $4.09 \mathrm{a}$ & 1.26 & 3.60 & 0.10 & 0.14 & 15.60 \\
\hline$P$ & $*$ & $\ddot{o} d$ & $\ddot{o ̈ d}$ & $\ddot{o d}$ & öd & öd \\
\hline
\end{tabular}

\section{Sonuç ve Öneriler}

Farklı toprak miseli uygulamasının beyaz şapkalı mantar (Agaricus bisporus) yetiştiriciliğinde verim ve kaliteye etkilerini belirlemek amacıyla yaptığımız bu çalışmada, toprak miseli takviyesinin toplam ve pazarlanabilir verimi, karpofor sayısı ve ağırlığını arttırdığı, mantar morfolojisini, pazarlanabilir ürün kalitesini ve miktarını olumlu etkilediği saptanmıştır. Elde edilen bu bulgular toprak miseli uygulamasının olumlu etkilerini anlatan önceki çalışmalar ile uyumlu bulunmuştur (Vedder, 1989; Samp, 1993; Royse and Beelman, 2016). Benzer şekilde Siddhant and Ukaogo (2017) pembe kayın mantarında (Pleurotus eous) yaptıkları çalışmada örtü toprağına misel sarılmış kompost $(0.1 \%$, w/w) ilavesinin erkencilik sağlamak yanında mantar biyokütlesini de olumlu yönde etkilediğini belirtmiştir. Zied et al. (2010) formaldehit ile dezenfekte ederek ve etmeyerek örtü toprağına uyguladıkları farklı dozlardaki $\left(0,200,400\right.$ ve $\left.600 \mathrm{~g} / \mathrm{m}^{2}\right)$ misel sardırılmış kompostun beyaz şapkalı mantar üretiminde verimi ve karpofor ağırlığını arttırdığını, erkencilik sağladığını belirtmişlerdir. Uygulama konuları içerisinde aynı gerekçeler ile formaldehit uygulanmayan $600 \mathrm{~g} / \mathrm{m}^{2}$ dozu önerilmiştir. Araştırmada karpofor ağırlığı 23.73-29.33 g arasında bulunmuş ve verim artışının da ortalama karpofor ağırlığında meydana gelen artıştan kaynaklandığı belirtilmiştir. Pekşen ve Günay (2009) ortalama karpofor ağırlığını 15.14-21.16 g olarak bulmuşlardır. Yürütülen bu çalışmada, ortalama karpofor ağırlığı 17.82 ile $22.72 \mathrm{~g}$ arasında değişmiş ve önceki çalışmalar ile uyumlu bulunmuştur. Ancak toprak miseli uygulamasının verimde meydana getirdiği artışın karpofor sayısı ve ağırlığındaki, pazarlanabilir ürün miktarındaki artıştan kaynaklandığı belirlenmiştir. Pazarlanabilir ürün miktarındaki artışın ise, misellerin buket şeklinde kümeleşmemesi nedeni ile düzenli çıkışlardan kaynaklandığı görülmüştür. Elde edilen toplam verim değeri 23.20-26.45 kg/100 kg kompost arasında değişmiş ve Çetin ve ark. (2016) tarafından belirtilen verim değerleri (18.44-27.20 kg/100 kg kompost) ile uyumlu bulunmuştur.

Toprak miseli uygulaması karpofor morfolojisini olumlu yönde etkilemiş, ölçülen parametreler genellikle A15 misel uygulamasında daha yüksek bulunurken, F1C1 misel uygulaması kontrol gurubu ile aynı istatistiksel grupta yer almıştır. Erdoğan ve ark. (2018) farklı sıcaklık uygulamalarının A. bisporus'da verim ve karpofor özellikleri üzerine etkilerini araştırdıkları çalışmalarında, misel ön gelişme ve 
karpofor aşamasındaki farklı sıcaklık derecelerine göre değişmekle birlikte karpofor ağırlığının 25.72$34.94 \mathrm{~g}$, şapka ağırlığının 14.56-23.50 g, sap ağırlı̆̆ının 8.5-12.95 g, şapka çapının 48.43-54.18 mm, şapka kalınlığının 19.74-24.85 mm, sap çapının 18.52-21.56 mm ve sap uzunluğunun 42.05-48.54 mm arasında değiştiğini belirlemişlerdir. Elde edilen bu sonuçların çalışmadan elde edilen sonuçlar ile uyumlu olduğu görülmektedir.

Şapka açıklığ 1 toprak miseli uygulamasından etkilenmiştir. A15 ve F1C1 toprak miseli uygulamasında şapkaların kontrole göre daha erken açıldığı ve hasat anındaki açıklık oranlarının kontrole göre yüksek olduğu görülmüştür. Aynı hasat anında F1C1uygulamasında şapkalar genellikle \%50 açılmış, A15 uygulamasında şapkalar \%20 açıklıkta olmuştur.

Toprak miseli uygulanmış ortamdan elde edilen karpoforlar daha parlak ve daha doygun bir beyaz renge sahip olmuşlardır. L değeri 87.89-90.78, a değeri 0.91-2.48, b değeri 14.23-14.58 arasında değişim göstermiştir. Mohapatra et al. (2010), kapalı şapkada yaptıkları ölçümde renk değerlerini L 90 \pm 5 , a $0.3 \pm 0.8$ ve b $10 \pm 2$ olarak belirlemişlerdir. Elde edilen renk değerleri farklı çalışma koşullarına göre değişmekle birlikte, birbirine yakın sonuçlar vermiştir.

Uygulamaların mantar vitamin $\mathrm{C}$ içeriğini etkilemediği görülmüştür. Beyaz şapkalı mantarların vitamin içeriğinin düşük olduğu ve 1.7 ile $6.9 \mathrm{mg} / 100 \mathrm{~g}$ arasında değiştiği önceki çalışmalarda belirtilmiştir (Mattila et al., 2001; Afiukwa et al., 2013). Yürütülen çalışmada vitamin C içeriği 5.34 ile $5.57 \mathrm{mg} / 100$ g arasında bulunmuş ve belirtilen değerler içerisinde kalmıştır.

Karpofor kalitesinde yapılan ölçümler şapka sertliğinin toprak miseli uygulaması ile azaldığını, bunun da ve kuru madde içeriğindeki azalmadan kaynaklandığını göstermiştir. Crisan and Sands (1978) genel olarak mantar içeriğini \%90 su ve \%10 kuru madde olarak belirtmiştir. Owaid (2015) yürüttüğü bir çalışmasında A. bisporus'un kuru madde miktarını \%6.92 ile 7.81; Pekşen ve Günay (2009) farklı kompost materyallerinden elde edilen beyaz şapkalı kültür mantarında kuru madde miktarını \% 7.679.10 arasında bulmuşlardır. Araştırmadan elde edilen veriler kontrol uygulamasında yüksek olmasına rağmen (\%9.33) toprak miseli uygulaması ile bu oranın \%7.21 (A15) ve \%8.72 (F1C1) şeklinde azaldığını ancak önceki çalışmalar ile uyumlu olduğunu göstermiştir. Bu azalmanın karpofor morfolojisindeki gelişmeye bağlı olarak kuru madde miktarındaki seyrelmeden kaynaklandığını düşünülmektedir.

Mantar şapkasında ölçülen element içeriklerinden sadece $\mathrm{N}$ içeriğinin toprak miseli uygulaması ile arttığını, diğer elementlerin uygulamalardan etkilenmediği görülmüştür. Element içerikleri N \%3.874.09, P \%1.26-1.50, K \%3.60-4.11, Ca \%0.10-0.11, Mg \%0.14-0.17, Fe 15.60-20.80 ppm arasinda değişmiştir. Beyaz şapkalı mantarın element içeriği ile ilgili yapılan önceki çalışmalar element içeriklerinin uygulamalara göre değişebileceğini ortaya koymuştur. Nitekim, yapılan farklı çalışmalarda Venter (1994) A. bisporus'un element içeriğini P 9600-18000 ppm, K 41000-44000 ppm, Ca 1228-2829 ppm, Mg 900-1236 ppm ve Fe 78-128 ppm olarak verirken, Mattila et al. (2001) P 12700-12900 ppm, K 46000-47000 ppm, Ca 130-250 ppm, Mg 1300-1400 ppm, Fe 28-48 ppm olarak bulmuştur. Toaso et al (1993) ise P 12600-12800 ppm, K 22400-29700 ppm, Ca 527-667 ppm, Mg 960-1000 ppm ve Fe 40-100 ppm bulmuştur. Yürütülen araştırmadan elde edilen değerler ppm'e çevrildiğinde Fe hariç diğer elementlerin verilen değerler ile uyumlu olduğunu, ancak Fe değerinin biraz düşük kaldığını göstermiştir. Bu sonuç farklı yetiştirme koşullarında element içeriklerinin farklı olabileceğini göstermektedir. Nitekim yürütülen farklı çalışmalarda $A$. bisporus'un demir içeriğini araştırmamızdan elde edilen sonuçlar ile uyumlu olarak 7.4-7.9 mg/kg (Çağlarırmak, 2009), 18.91-23.81 mg/kg (Owaid, 2015) bulan araştırmacılar da mevcuttur.

Kullanılan toprak misellerinin olumlu etkilerine rağmen genotip farklılıkları nedeni ile etkilerinin farklı olduğu görülmüştür. Çalışmada kullanılan toprak miselleri içerisinde A15'in daha iyi performansa sahip olduğu ve beyaz şapkalı mantar üretiminde toprak miseli olarak kullanılmasının mantar üretiminde etkili olacağı belirlenmiştir. Ancak bu tür çalışmaların farklı toprak miselleri, uygulama dozu ve yeri (komposta veya örtü toprağına) ile ilgili çalışmalara devam edilmesi önerilmektedir.

\section{Teșekkür}

Araştırmamıza misel ekili kompost sağlayarak katkıda bulunan PE-MA Mantar İşletmesi (Foça/İzmir) sahibi Sayın Orhan PEMBE'ye ve toprak miseli temini konusunda Ege Üniversitesi Bergama Meslek Yüksekokulu Mantarcılık Programı’ndan Dr. Öğr. Üy. Erkan EREN’e teşekkür ederiz.

\section{Kaynaklar}

Afiukwa, C.A., Ugwu, O.P.C., Okoli, S.O., Idenyi, J.N. \& Ossai, E.C. (2013). Contents of some vitamins in five edible mushroom varieties consumed in Abakaliki Metropolis, Nigeria. Research Journal of Pharmaceutical, Biological and Chemical Sciences, 4(2), 805-812.

7 I P a g e

www.iiste.org 
Anonymus, (2020). Casing Inoculum. http://www.sylvaninc.com/casing-inoculum/ (25 Nisan 2020).

Aksu, Ş., (2006). Kültür Mantarı Üretim Teknikleri, Hasad Yayıncılık, İstanbul. 112 s.

Basım, V. (2019). Türkiye'nin mantar başkenti: Korkuteli, Türk Tarım Orman Dergisi, 252, 13-15.

Çetin, M., Özaktan, H. \& Boztok, K. (2016). Örtü toprağında bulunan bazı yararlı bakterilerin kültür mantarı Agaricus bisporus'un gelişim ve verimi üzerine etkileri. Türk Tarım-Gıda Bilim ve Teknolojisi Dergisi, 4 (3), 197-203.

Caglarırmak, N. (2009). Determination of nutrients and volatile constituents of Agaricus bisporus (brown) at different stages. Journal of Science of Food and Agriculture, 89, 634-638. https://doi.org/10.1002/jsfa.3493

Crisan, E.V. \& Sands, A. (1978). Nutritional value. In: Chang, S.T. \& Hayes, W.A. editors. The biology and cultivation of edible mushrooms. U.S.A.: New York Academic Press; pp. 137-165.

Erdoğan, F., Paksoy, M., Seymen, M. \& Türkmen, Ö. (2018). Farklı sıcaklık uygulamalarının mantarda (Agaricus bisporus (Lange) Sing.) verim ve karpofor özellikleri üzerine etkileri. Manas Journal of Agriculture Veterinary and Life Sciences, 8 (2), 70-77.

FAOSTAT, (2020). Food and Agriculture Data. http:/www.fao.org/faostat/en/\#data/QC (15 Nisan 2020)

MacCanna, C. \& Flanagan, J.B. (1972). Casing types and techniques. Mushroom Science, 3,727731.

Mattila, P., Konko, K., Eurola, M., Pihlawa, J.M., Astola, J., Vahteristo, Lietaniemi, V., Kumpulainen, J., Valtonen, M. \& Piironen, V. (2001). Contents of vitamins, mineral elements, and some phenolic compounds in cultivated mushrooms. Journal of Agricultural and Food Chemistry, 49, $2343-$ 2348. https://doi.org/10.1021/jf001525d

Mohapatra, D., Bira, Z.M., Kerry, J.P., Frias, H.M. \& Rodrigues, F.A. (2010). Postharvest hardness and color evolution of white button mushrooms (Agaricus bisporus). Journal of Food Science, 75 (3), 146-152. https://doi.org/10.1111/j.1750-3841.2010.01518.x

Munshi, N.A., Hassan Dar, Gh., Ghani, M.Y., Kauser, S. \& Mughal, N. (2010). Button Mushroom Cultivation. Communication and Publication Centre Sher-e-Kashmir University of Agricultural Sciences and Technology of Kashmir Shalimar Srinagar 191121 Jammu and Kashmir, India. 28 p.

Owaid, M.N. (2015). Mineral elements content in two sources of Agaricus bisporus in Iraqi market. Journal of Advanced \& Applied Sciences, 3 (2), 46-50.

Pekşen, A.\& Günay, A. (2009). Kültür mantarı (Agaricus bisporus (L.) Sing.) yetiştiriciliğinde çay atığı ve buğday sapı karışımından hazırlanan kompostların kullanımı. Ekoloji, 19, 73, 48-54. https://doi.org/10.5053/ekoloji.2009.736

Royse, D.J. \& Beelman, R.B. (2016). Six Steps to Mushroom Farming. Publication of College of Agricultural Sciences Agricultural Research and Cooperative Extension, The Pennsylvania State University. Penn State Extension, https://extension.psu.edu/six-steps-to-mushroom-farming, 20 p.

Samp, R. (1993). Developments in spawned casing. Mushroom Journal, 523,14-15.

Siddhant, O.Y.S. \& Ukaogo, O.P. (2017). Spawned casing vs simple casing. Asian Journal of Advances in Agricultural Research, 4(1): 1-5, Article no.AJAAR.38476. https://doi.org/10.9734/ajaar/2017/38476 
Şen, S. \& Yalçın, M. (2010). Dünya ve Türkiye'de kültür mantarcıllğı ve geliştirilmesi, III. Ulusal Karadeniz Ormanc1lık Kongresi, 20-22 Mayıs 2010. 3, 1208-1216.

Toaso, G., Schmid, R. \& Fodor, P. (1993). Studies on the selenium content of champignon (Agaricus bisporus) grown on substrate with higher selenium level. Acta Agronomica Óvariensis 35, 73-86.

Vedder, P.J.C. 1989. Practical experience with the CAC'ing technique. Mushroom Science, 8:381385.

Vetter, J. (1994). Mineral elements in the important cultivated mushrooms Agaricus bisporus and Pleurotus ostreatus. Food Chemistry, 50, 277-279. https://doi.org/10.1016/0308-8146(94)901325

Zied, D.C., Minhoni, M.T.A., Pardo-Gonzalez, J.E. \& Padro-Gimenez, A. (2010). A study of compost added to a casing technique in Agaricus bisporus cultivation from phase III bulk compost. Hortscience, 45(11),1649-1653. https://doi.org/10.21273/hortsci.45.11.1649 